\title{
Impossible until implemented: New Zealand shows the way
}

\author{
Mike Daube $\odot,{ }^{1}$ Raglan Maddox ${ }^{2}{ }^{2}$
}

The past 50 years have seen many developments in tobacco that we now take for granted but were once unthinkable. In those earlier days, smoking was permitted almost everywhere-restaurants, workplaces, schools and even in the WHO's Geneva headquarters. Tobacco advertising was pervasive and enticing. Cigarette packs were glossy. Public education relied on occasional posters and leaflets. Health warnings were insipid. Cigarettes were taxed-but not at levels to cause the manufacturers discomfort. A major airline's response to a 1970s survey assured one of us (MD) that restrictions on smoking in aircraft were technically impossible. Among governments, Cornford's dictum about academe dominated-'Every public action which is not customary, either is wrong, or, if it is right, is a dangerous precedent. It follows that nothing should ever be done for the first time'. ${ }^{1}$

The epidemic is still with us, fuelled by counterattacks from a resurgent tobacco industry-but there has also been remarkable progress, showing the art of the possible. And an important lesson we have learnt is that while measures recommended by health authorities are attacked and derided by the industry and its allies as impossible, illegal, ineffective, unworkable and counterproductive, once successfully introduced in one country or state they can be recognised as best practise and speedily implemented elsewhere.

Tobacco advertising seemed untouchable. Then in 1973 Norway legislated an ad ban, taking effect from 1975. ${ }^{2}$ The sky did not fall in-and other countries followed. Strong, varying health warnings were impossible-then in 1977 Sweden introduced 16 rotating warnings-and other countries strengthened theirs. Smokefree measures were a hard ask-but several US states and other countries led the way, and Ireland showed that smoking

\footnotetext{
${ }^{1}$ Faculty of Health Sciences, Curtin University, Perth, Western Australia, Australia

${ }^{2}$ Aboriginal and Torres Strait Islander Health Program, National Centre for Epidemiology and Public Health, Australian National University, Acton, Australian Capital Territory, Australia
}

Correspondence to Professor Mike Daube, Faculty of Health Sciences, Curtin University, Perth, Western Australia, Australia; m.daube@curtin.edu.au could even be banned in Dublin pubs. In Australia, Victoria showed that tobacco taxes could be increased with popular support and used to replace tobacco sponsorship; while Australia also demonstrated that hard-hitting media campaigns actually work. ${ }^{3}$ New Zealand showed that with a well-implemented programme, smoking can be successfully banned in prisons. ${ }^{4}$ Tobacco plain packaging was so fiercely opposed by Big Tobacco that it just could not happen. Then, it was implemented in Australia in 2012, and speedily followed by many more countries. ${ }^{5}$

And so it goes: impossible until implemented in one jurisdiction, and then the dominos fall.

Nevertheless, tobacco control measures have generally been introduced on a piecemeal basis, each one fiercely opposed and hard-fought. A critically important target remains the implementation of comprehensive national strategies including all the key recommendations from WHO and other health authorities. No country has yet done this—so it must be impossible.

The New Zealand Government's 'Proposals for a Smokefree Aotearoa 2025 Action Plan', 6 recently released by Associate Health Minister Dr Ayesha Verrall, sets the tone for a new and innovative approach. ${ }^{7}$ This differs in three important ways from the myriad plans and strategies released by other governments over the years.

First, it is comprehensive. The proposals include enhancing existing activities, such as mass media, cessation support and smokefree measures, alongside new, game-changer approaches-reducing the number of sales outlets, regulating tobacco products to make them less attractive and addictive (including reducing nicotine to very low levels and banning filters) and gradually phasing out the legal sale of cigarettes by prohibiting sales of smoked tobacco products to new cohorts from a specified date (the 'Smokefree Generation' policy). This will be supported by strong compliance and enforcement, increased investment in research, evaluation and monitoring, and community-level action. All this is underpinned by a commitment to eliminate disparities in smoking, building on the leadership, engagement and Māori governance of tobacco control efforts-consistent with the WHO Framework Convention on Tobacco Control (FCTC) Guiding Principles to engage Indigenous peoples in the development, implementation and evaluation of tobacco control.

Second, the targets for further and accelerated declines in smoking are not set, as occurs with so many political targets, for a time when current politicians have retired and can no longer be held to account-but for 2025, as earlier recommended by the Māori Health Select Committee, ${ }^{8}$ when adult daily prevalence is anticipated to be at or below $5 \%$.

Third, New Zealand is bound by the WHO FCTC, ${ }^{9}$ where Article 5.3 confirms the tobacco industry's pariah status, precluding tobacco companies and associated interests from any influence over public health policies.

The programme is ambitious-but if anywhere can get there, it is New Zealand. As their handling of COVID-19 has shown, they have an excellent public health system, complemented by strong non-government and research sectors and a Government willing to prioritise health protection. The proposals will be fiercely opposed by Big Tobacco, along with the usual array of industry organisations, lobbyists, lawyers and front groups, all trying to circumvent the FCTC, to prevent anything that might reduce smoking and to attack and undermine health authorities, ${ }^{10} 11$ Indigenous sovereignty and sovereign governments. But New Zealand is well placed to resist these pressures. The international tobacco companies are not as powerful there as in many other countries (even though they will inevitably bring in their big battalions); the tawdry tactics of tobacco lobbyists and front groups have recently been well exposed in the media $^{12} 13$; and even the tobacco companies' own documents show that nowadays they are having trouble attracting good staff. $^{14}$

The success of the plan will depend on continuing commitment, robust implementation and adequate resourcing. But if that eventuates, the impact will be seen far beyond New Zealand's borders. Less than a decade after the impossible target of tobacco plain packaging was achieved, it has been legislated in a further 17 countries, with more to come. If New Zealand sets a precedent with a strong, comprehensive approach, alongside bold but achievable targets, the same course of action will similarly be vastly easier for others.

The proposed plan is of course still just that-a plan. Health organisations, experts and all who want to foster an 
environment for future generations to be smoke-free, and to end this entirely preventable epidemic, can play a role. We encourage all our colleagues to show support for the proposals, with submissions at https://www.health. govt.nz/publication/proposals-smokefree-aotearoa-2025-action-plan and continuing action to counter the inevitable opposition from the world's most lethal industry.

Tobacco kills 4500 people each year in New Zealand, but more than 8 million globally. Minister Verrall and the New Zealand Government deserve great praise for their excellent, world-leading plan. Their exemplar role can be crucial in saving thousands of lives in their own country and millions of lives around the world.

Twitter Raglan Maddox @RaglanMaddox

Contributors Both authors contributed to the concept and authorship.

Funding The authors have not declared a specific grant for this research from any funding agency in the public, commercial or not-for-profit sectors.

Competing interests None declared.

Patient consent for publication Not required.

Provenance and peer review Not commissioned; internally peer reviewed.

(c) Author(s) (or their employer(s)) 2021. No commercial re-use. See rights and permissions. Published by BMJ.

$$
\text { D Check for updates }
$$

To cite Daube M, Maddox R. Tob Control 2021;30:361-362.

Published Online First 24 May 2021

Tob Control 2021;30:361-362.

doi:10.1136/tobaccocontrol-2021-056776

\section{ORCID iDs}

Mike Daube http://orcid.org/0000-0002-3479-2785

Raglan Maddox http://orcid.org/0000-0002-2770-0686

\section{REFERENCES}

1 Wikipedia. Microcosmographia Academica, 2021. Available: https://en.wikipedia.org/wiki/ Microcosmographia_Academica [Accessed 5 May 2021].

2 Campaign for Tobacco-Free Kids. Legislation. tobacco control laws. Washington: campaign for tobacco-free kids, 2021. Available: https://www.tobaccocontrollaws. org/legislation [Accessed 5 May 2021].

3 Durkin S, Brennan E, Wakefield M. Mass media campaigns to promote smoking cessation among adults: an integrative review. Tob Control 2012;21:127-38.

4 Collinson L, Wilson N, Edwards R, et al. New Zealand's smokefree prison policy appears to be working well: one year on. $N Z$ Med J 2012;125:164-8.

5 Scollo M, Greenhalgh E. 11A.6 International flow-on effects. In: Greenhalgh E, Scollo M, Winstanley M, eds. Tobacco in Australia: facts and issues. Melbourne: Cancer Council Victoria, 2021. https://www. tobaccoinaustralia.org.au/chapter-11-advertising/ indepth-11a-packaging-as-promotion/11a-6international-flow-on-effects

6 Ministry of Health. Proposals for a Smokefree Aotearoa 2025 action plan: discussion document. Wellington: Ministry of Health, 2021. https://www.health.govt. nz/publication/proposals-smokefree-aotearoa-2025action-plan

7 Edwards R and members of the ASPIRE 2025 Research Centre. New Zealand government proposes worldleading action plan to achieve Smokefree goal. tobacco control, 2025. Available: https://blogs.bmj.com/tc/ [Accessed 15 May 2021].

8 New Zealand Parliament. Inquiry into the tobacco industry in Aotearoa and the consequences of tobacco use for Māori. Report of the Māori Affairs select Committee. Wellington: New Zealand Parliament, 2010. https://www.parliament.nz/en/pb/sc/reports/ document/49DBSCH_SCR4900_1/inquiry-into-thetobacco-industry-in-aotearoa-and-the-consequences

9 World Health Organization. Framework convention on tobacco control: who regional office for south-east Asia, 2004. Available: https://apps.who.int/iris/handle/ 10665/206081 [Accessed 5 May 2021].

10 Waa A, Robson B, Gifford $\mathrm{H}$, et al. Foundation for a smoke-free world and healthy Indigenous futures: an oxymoron? Tob Control 2020;29:237.

11 Waa A, Maddox R, Nez Henderson P. Big tobacco using Trojan horse tactics to exploit Indigenous peoples. Tob Control 2020;29:e132.

12 Espiner G. Dirty politics: SAGA ends with Carrick Graham apology in court. radio New Zealand, 2021. Available: https://www.rnz.co.nz/news/national/ 437562/dirty-politics-saga-ends-with-carrick-grahamapology-in-court [Accessed 5 May 2021].

13 Braae A. Crushing defeat for dirty politics PR man with apology to defamed academics. The Spinoff, 2021. Available: https://thespinoff.co.nz/media/03-03-2021/ crushing-defeat-for-dirty-politics-pr-man-with-apologyto-defamed-academics/ [Accessed 5 May 2021].

14 Altria. Altria Reports 2021 First-Quarter Results; Reaffirms 2021 Earnings Guidance; Acquires Remaining $20 \%$ of Global on! Business. Richmond: Altria Group Inc, 2021. Available: https://investor. altria.com/press-releases/news-details/2021/AltriaReports-2021-First-Quarter-Results-Reaffirms-2021Earnings-Guidance-Acquires-Remaining-20-of-Globalon-Business/default.aspx [Accessed 5 May 2021]. 